\title{
BIOSYNTHESIS OF $\triangle$-AMINOLEVULINATE IN GREENING BARLEY LEAVES. VII. GLUTAMATE 1-SEMIALDEHYDE ACCUMULATION IN GABACULINE TREATED LEAVES
}

\author{
by \\ C. GAMINI KANNANGARA ${ }^{1)}$ and ARNE SCHOUBOE ${ }^{2)}$ \\ " Department of Physiology, Carlsberg Laboratory, \\ Gamle Carlsberg Vej 10, DK-2500 Copenhagen Valby \\ ${ }^{2)}$ Quality Services, United Breweries Ltd., Vesterfælledvej 100, \\ DK-1799 Copenhagen V.
}

Keywords: Chlorophyll biosynthesis, glutamate 1-semialdehyde aminotransferase inhibition

Chlorophyll formation in etiolated barley leaves is inhibited by treatment with $500 \mu \mathrm{M}$-3-amino-2,3-dihydrobenzoic acid (gabaculine). Significant amounts of glutamate 1-semialdehyde and small amounts of $\delta$-aminolevulinate accumulated in the treated leaves. Aerobic conditions and light stimulated the accumulation of glutamate 1-semialdehyde. Gabaculine $(5 \mu \mathrm{M})$ inhibited the activity of purified glutamate 1-semialdehyde aminotransferase by $83 \%$. This inhibition was irreversible and required the presence of either glutamate 1-semialdehyde or $\delta$-aminolevulinate. The mass and infrared spectra of glutamate 1 -semialdehyde formed in gabaculine treated leaves were identical to the spectra of the chemically synthesised compound. The experiments confirm that glutamate 1 -semialdehyde participates as an intermediate in chlorophyll biosynthesis. Glutamate 1-semialdehyde hydrochloride was stable.

\section{INTRODUCTION}

Recently it has been reported that 3-amino2,3-dihydrobenzoic acid (gabaculine) is a potent inhibitor of chlorophyll synthesis in higher plants and algae (4). Since this inhibition could be counteracted by supply of $\delta$-aminolevulinic acid it was inferred that gabaculine blocks chlorophyll synthesis at a step prior to $\delta$-aminolevulinate. It was suggested that the site of inhibition is a pyridoxal phosphate-linked transaminase. It therefore appeared of interest to examine the effects of gabaculine in greening barley where some of the enzymes involved in $\delta$-aminolevulinate synthesis have been characterised in detail.

\section{MATERIALS AND METHODS}

\subsection{Chemicals}

3-Amino-2,3-dihydrobenzoic acid hydrochloride (gabaculin) was obtained from Fluka AG, Switzerland. N-CBZ-L-glutamic acid- $\gamma$ benzyl ester was from Bachem AG, Switzerland. Palladium powder was from Aldrich-Chemie GmbH \& Co. KG, W. Germany. Phosphorus pentachloride was obtained from Merck, W.

Abbreviations: $\delta$-ALA-RNA $=$ the RNA involved in the conversion of glutamate to $\delta$-aminolevulinate; $\mathrm{CBZ}=$ carbobenzoxy; Tris $=$ Tris(hydroxymethyl)aminomethane. 
Germany. 3-Methyl-2-benzothiazolinone hydrazone (MBTH) was obtained from Sigma, St. Louis, Mo., USA.

\subsection{Plant material}

Barley seeds (Hordeum vulgare L cv. Svalof's Bonus) were germinated and grown in moist vermiculite as described previously (9). Seedlings were grown for six days in darkness. Either entire seedlings or leaf segments were illuminated with "Osram Fluora" florescent light at $2.59 \mathrm{~W} \cdot \mathrm{M}^{-2}$.

\subsection{Enzymes and $\delta$-ALA-RNA}

The components involved in the enzymic conversion of glutamate to $\delta$-aminolevulinate were isolated and separated into three fractions by passing a plastid stroma fraction sequentially through blue-Sepharose, Matrex gel A and chlorophyllin-Sepharose. This procedure is described in detail in (9) and (15) and summarised in Figure 1. The blue-Sepharose bound fraction contained the aminoacyl ligase involved in $\delta$ aminolevulinate synthesis (cf. 9) and was used without further purification. The chlorophyllinSepharose bound fraction contained the $\delta$-ALARNA and was isolated and purified by High Pressure Liquid Chromatography as described in (9). The fraction not bound by the three affinity columns contained $\delta$-aminolevulinate dehydratase, porphobilinogen deaminase and glutamate 1-semialdehyde aminotransferase. This fraction was used either directly or after purification of glutamate 1-semialdehyde aminotransferase by preparative gel electrophoresis. A $2 \mathrm{~mm}$ thick, $7 \%$ polyacrylamide slab gel overlayered with a $2.5 \%$ stacking gel was prepared using the stock solutions described by DAvis (3). The Tris-glycine buffer described by DAvIS (3) was used for electrophoresis. After electrophoresis the gel was sliced transversely and each slice ground separately in liquid $\mathrm{N}_{2}$. The powdered gel was then suspended in $3 \mathrm{ml} 0.3 \mathrm{M}$-glycerol, 0.1 M-Tricine- $\mathrm{NaOH} \mathrm{pH} \mathrm{9.0,1} \mathrm{mM-dithiothrei-}$ tol and $25 \mathrm{~mm}-\mathrm{MgCl}_{2}$. The suspension was periodically shaken for 10 minutes at room temperature. The gel pieces were then removed by centrifugation at $5000 \mathrm{~g}$ for 10 minutes. Aliquots of the supernatant were assayed for glutamate 1-semialdehyde aminotransferase as given in 2.4.

\footnotetext{
Plastid stroma protein
}

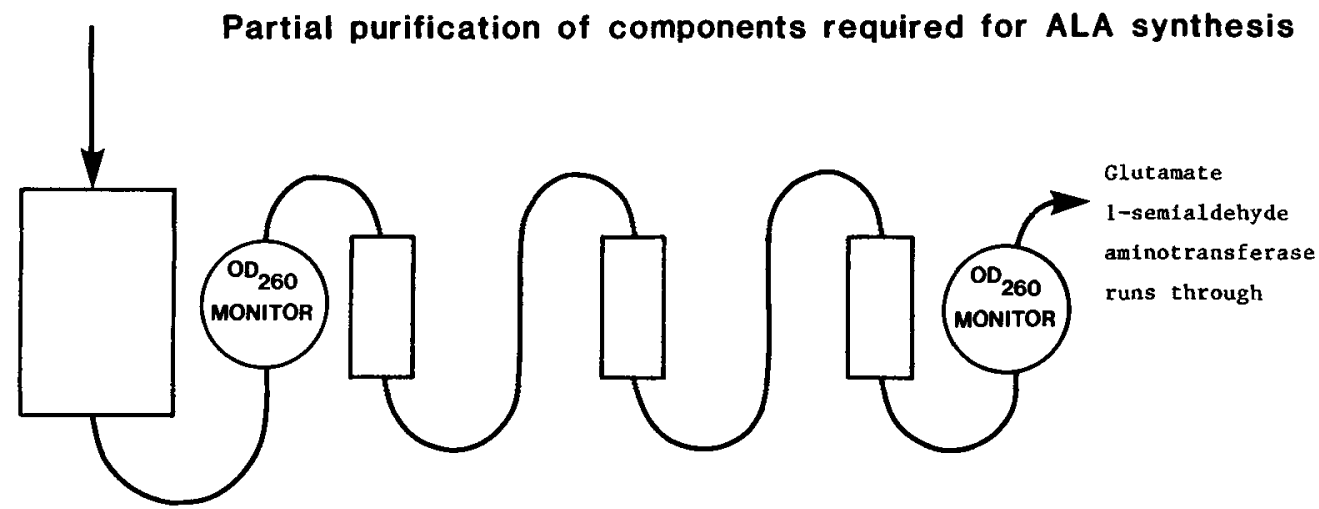

Sephacryl S-300 gel

filtration removes

high and low mol.wt. contaminants.
Cibacron blue-Sepharose binds Aminoacyl ligase

\& Dehydrogenase.
Procion red-Agarose removes several contaninating proteins.
Chlorophyllen or Heme-Sepharose binds 8-ALA-RNA.

Figure 1. The flow diagram for isolation of the components involved in $\delta$-aminolevulinate synthesis in greening barley (cf.9 \& 15) 


\subsection{Glutamate 1-semialdehyde amino- transferase assay}

The reaction mixture contained in a total volume of $1 \mathrm{ml}$ : $0.3 \mathrm{M}$-glycerol, $0.1 \mathrm{M}$-Tricine$\mathrm{NaOH}$ pH 7.9, 1 mM-dithiothreitol, $25 \mathrm{~mm}$ $\mathrm{MgCl}_{2}, 0.8$ to $2 \mathrm{mM}$-glutamate 1 -semialdehyde and 10 to $100 \mu \mathrm{g}$ enzyme protein. The mixture was incubated for 20 minutes at $28{ }^{\circ} \mathrm{C}$. Twenty five $\mu \mathrm{l}$ of $70 \%$ perchloric acid was added to stop the reaction. The precipitated protein was removed by centrifugation. The $\delta$-aminolevulinate formed was determined after condensing it with ethylacetoacetate to a pyrrole and reacting the pyrrole with modified Ehrlich's reagent as described in (15).

\subsection{Gabaculine treatment}

Leaves were treated with gabaculine either by feeding from cut ends or by infiltration. The procedure of gabaculine feeding was as follows: The apical centimeter of the leaf was removed and a clean cut was made at the base of the leaf to give an approximately $6 \mathrm{~cm}$ long segment. The segments were placed upright in a beaker with one $\mathrm{cm}$ of their basal cut ends dipping in $500 \mu \mathrm{M}$-gabaculine in water and illuminated. In the control experiments the basal ends of the leaf segments were immersed in water. In the experiments using etiolated leaves the preparation of the leaf segments was performed in dim room light. A small fan was used to move the air above the leaves and facilitate uptake of solution.

Infiltration of gabaculine was carried out with five $\mathrm{g}$ fresh weight of leaf tissue cut into one $\mathrm{cm}$ pieces. These pieces were placed in a $100 \mathrm{ml}$ conical flask containing $20 \mathrm{ml}$ of $500 \mu \mathrm{M}$-gabaculine $\left(\mathrm{H}_{2} \mathrm{O}\right.$ for control). Suction was applied to the flask using a water aspirator. The flask was periodically shaken and the vacuum released. This process was repeated until the leaf pieces sank in the liquid. Leaf pieces were removed from the solution after incubation and rinsed with water.

\subsection{Extraction of glutamate 1-semialdehyde from leaves}

In the experiments in which the kinetics of glutamate 1-semialdehyde accumulation was analysed (Figure 3), five $g$ fresh weight of leaf tissue was cut into $1 \mathrm{~mm}$ segments and ground using a mortar and pestle with $10 \mathrm{ml}$ of ice cold $0.1 \mathrm{~N}-\mathrm{HCl}$ containing $5 \% \mathrm{H}_{3} \mathrm{PO}_{4}$. In all other experiments leaf tissue was frozen in liquid $\mathrm{N}_{2}$ and ground into a fine powder. The powder from five $\mathrm{g}$ of tissue was suspended in $15 \mathrm{ml}$ of 0.1 $\mathrm{N}-\mathrm{HCl}$ at room temperature and shaken for about 10 minutes. The leaf debris was removed by centrifugation at $20.000 \mathrm{~g}$ and the supernatant analysed as described in 2.7 .

\subsection{Purification of glutamate 1-semialdehyde and $\delta$-aminolevulinate formed in vivo}

The extract from $5 \mathrm{~g}$ fresh weight of leaves was purified using a bed of Dowex 50X8 $(0.6 \times 2.0$ $\mathrm{cm})$ packed in a Bio-Rad Econocolumn. The column was packed using water and washed with $2 \mathrm{ml}$ of $1 \mathrm{~N}-\mathrm{NaOH}$ followed by $3 \mathrm{ml}$ of 0.2 $\mathrm{M}$-sodium citrate buffer $\mathrm{pH} 3.1$. Fifteen to $20 \mathrm{ml}$ of leaf extract was loaded onto the column and washed with $8 \mathrm{ml}$ of $0.2 \mathrm{M}-\mathrm{Na}$-citrate buffer $\mathrm{pH}$ 3.1 followed by $1 \mathrm{ml}$ of $0.2 \mathrm{M}$-Na-citrate buffer pH 4.1. Thereafter glutamate 1-semialdehyde was eluted using $3 \mathrm{ml}$ of $0.2 \mathrm{M}$-Na-citrate buffer $\mathrm{pH}$ 4.1. After eluting the glutamate 1-semialdehyde, the column was washed with $1 \mathrm{ml}$ of 0.2 M-Na-citrate buffer $\mathrm{pH} 4.1$ and $\delta$-aminolevulinate was eluted with $4 \mathrm{ml}$ of $0.2 \mathrm{M}-\mathrm{Na}$-citrate buffer pH 5.1.

\subsection{Large scale extraction and purification of glutamate 1-semialdehyde from gabaculine treated leaves}

Leaf segments ( $450 \mathrm{~g}$ fresh weight) from six day old dark-grown barley seedlings were fed with $500 \mu \mathrm{M}$-gabaculine overnight (ca. $18 \mathrm{~h}$ ) in the light at $23{ }^{\circ} \mathrm{C}$ as described in 2.5 . The leaf segments were then frozen in liquid $\mathrm{N}_{2}$ and ground to a fine powder and suspended in 1.2 litres of $0.1 \mathrm{~N}-\mathrm{HCl}$. The suspension was stirred for 30 minutes at room temperature and cell debris removed by centrifugation at $10,000 \mathrm{~g}$. The supernatant was divided into 250 to $300 \mathrm{ml}$ portions and stored frozen. Initial purification was performed batchwise using Dowex $50 \mathrm{X} 8$ columns $(0.6 \times 28 \mathrm{~cm})$ and an $\mathrm{HCl}$ elution system. Each column was washed with $50 \mathrm{ml}$ of 1 
$\mathrm{N}-\mathrm{NaOH}$ and equilibrated with $50 \mathrm{~mm}-\mathrm{HCl}$. The leaf extract (up to $300 \mathrm{ml}$ ) was loaded to the column and was washed with $20 \mathrm{ml}$ of 0.1 $\mathrm{N}-\mathrm{HCl}$. Thereafter $0.5 \mathrm{~N}-\mathrm{HCl}$ was applied to the column and eluate collected in $2 \mathrm{ml}$ fractions. Aliquots $(50 \mu 1)$ from the fractions were assayed as given in 2.10. Five Dowex columns were used for the initial fractionation of the extract from $450 \mathrm{~g}$ of gabaculine treated tissue and the fractions containing glutamate 1 -semialdehyde were pooled and lyophilised. Radioactive $\delta$-aminolevulinate and glutamate were used to monitor the effectiveness of the Dowex-HCl chromatography. At this step glutamate 1-semialdehyde was obtained well resolved from $\delta$-aminolevulinate but not from glutamate. The lyophilised material was dissolved in $40 \mathrm{ml}$ of water and chromatographed on a Dowex $50 \mathrm{X} 8$ column $(0.6 \times 28 \mathrm{~cm})$ using $0.2 \mathrm{M}$-Na-citrate buffer to remove glutamate. The column was prepared by washing with $50 \mathrm{ml}$ of $1 \mathrm{~N}-\mathrm{NaOH}$ and equilibrating with $0.2 \mathrm{M}-\mathrm{Na}$-citrate buffer at $\mathrm{pH}$ 3.1. After loading the glutamate 1-semialdehyde preparation the column was washed with $40 \mathrm{ml}$ of pH $3.1 \mathrm{Na}$-citrate buffer. Thereafter $0.2 \mathrm{M}$ Na-citrate buffer $\mathrm{pH} 5.1$ was applied to the column and eluate collected in $2 \mathrm{ml}$ fractions. The glutamate 1-semialdehyde containing fractions were identified by assaying aliquots from the fractions. To each of these fractions $50 \mu \mathrm{l}$ of $4 \mathrm{~N}-\mathrm{HCl}$ was added. These fractions were pooled and diluted with an equal volume of water. This solution was immediately rechromatographed on a Dowex $50 \times 8$ column using $\mathrm{HCl}$ as described above and the glutamate 1-semialdehyde containing fractions pooled and lyophilised. The two chromatography steps, one using the citrate buffer followed by the other employing $\mathrm{HCl}$ were repeated. From $450 \mathrm{~g}$ of gabaculine treated leaves, $16.5 \mathrm{mg}$ of glutamate 1 -semialdehyde hydrochloride was isolated.

\subsection{Chemical synthesis and purification of} glutamate 1-semialdehyde hydrochloride

Glutamate 1-semialdehyde was synthesised using N-carbobenzoxy L-glutamate 5-benzyl ester as starting material as decribed in (7) with several modifications. Eight $g$ of starting material was placed in a conical flask and dissolved in
$500 \mathrm{ml}$ of diethyl ether. The flask was closed with a glass stopper and cooled in a salt-ice bath $(-20$ $\left.{ }^{\circ} \mathrm{C}\right)$. Phosphorous pentachloride $(8 \mathrm{~g})$ was added and the solution vigorously shaken until the $\mathrm{PCl}_{5}$ dissolved. This solution was incubated in a salt-ice bath for 50 minutes with periodic shaking. After incubation the solution was transferred into a one litre measuring cylinder containing $10 \mathrm{~g}$ of palladium black and $100 \mu \mathrm{l}$ of quinoline poison (cf.7). Palladium black was freshly prepared and dried by washing with acetone followed by diethyl ether. The cylinder was placed in an ice bath with a stream of $\mathrm{H}_{2}$ passing through the solution. Magnetic stirring was used to keep Pd black distributed evenly in the solution during hydrogenation and diethyl ether was added periodically to keep the volume of the mixture around $500 \mathrm{ml}$. After 5.5 hours of hydrogenation, a white turbidity appeared in the ether and $100 \mathrm{ml}$ of water was added to clarify the mixture. The hydrogenation was continued for further 30 minutes. The liquid layers were removed from the Pd black by filtration through a sintered glass funnel. The Pd black was washed three times with $50 \mathrm{ml}$ aliquots of water and the washings collected into the ether fraction. The aqueous layer was collected using a separatory funnel. The ether layer was washed twice with water and the washings combined with the aqueous layer. At this stage a turbidity appeared and $10 \mathrm{ml}$ of $2 \mathrm{~N}-\mathrm{HCl}$ was added which clarified the solution. The clarified solution was lyophilised and dissolved in $40 \mathrm{ml}$ of water. Glutamate 1 -semialdehyde was isolated from this solution by chromatography on two Dowex $50 \times 8$ columns first using the $\mathrm{Na}$-citrate buffer procedure followed by the $\mathrm{HCl}$ procedure described in 2.8 . After lyophilisation $166 \mathrm{mg}$ of glutamate 1semialdehyde hydrochloride was obtained.

\subsection{Determination of glutamate 1- semialdehyde}

Three different assays were used for glutamate 1-semialdehyde determination. Two assays, one with Ehrlich's reagent and the other with 3-methyl 2-benzothiazolinone hydrazone (MBTH) were used for qualitative and quantitative analysis. The glutamate 1-semialdehyde aminotransferase assay (cf.2.4) was used for 
qualitative analysis. For dependable quantitative analysis it was found necessary to perform all three assays in parallel.

\subsubsection{Determination of glutamate 1- semialdehyde with Ehrlich's reagent}

A glutamate 1-semialdehyde solution was adjusted to pH 6.9 using $0.5 \mathrm{M}-\mathrm{Na}_{3} \mathrm{PO}_{4}$ and 0.5 $\mathrm{M}-\mathrm{NaH}_{2} \mathrm{PO}_{4}$. Ethylacetoacetate $(100 \mu \mathrm{l})$ was added and the mixture incubated for 20 minutes at $100{ }^{\circ} \mathrm{C}$. The solution was cooled to room temperature and an equal volume of modified Ehrlich's reagent added. After 20 minutes optical density at $553 \mathrm{~nm}$ was measured against an appropriate blank. The amount of glutamate 1-semialdehyde was calculated using $\mathrm{E}_{\mathrm{mm}}=1$. $\delta$-Aminolevulinate strongly interferes with this assay. Therefore, this procedure was used only with preparations purified from $\delta$-aminolevulinate by Dowex chromatography.

\subsubsection{Determination of glutamate 1- semialdehyde using 3-methyl 2- benzothiazolinone hydrazone}

Fifty $\mu \mathrm{l}$ from a $4 \%$ stock solution of 3-methyl 2-benzothiazolinone hydrazone in water was added to $0.5 \mathrm{ml}$ of glutamate 1-semialdehyde solution. The mixture was then heated for 2 minutes at $98.5^{\circ} \mathrm{C}$ to $100^{\circ} \mathrm{C}$ and rapidly cooled in a water bath to room temperature. One $\mathrm{ml}$ of water and $50 \mu \mathrm{l}$ of $20 \% \mathrm{FeCl}_{3}$ were added. After 5 minutes $2 \mathrm{ml}$ of water was added and the optical density at $620 \mathrm{~nm}$ measured against an appropriate blank. The amount of glutamate 1 -semialdehyde was calculated using $\mathrm{E}_{\mathrm{mm}}=16.9$. This procedure was developed from the aldehyde assay described in (13). $\delta$-Aminolevulinate does not interfere in this assay, but several other aldehydes do so (cf.13).

\subsection{Infrared spectroscopy}

Approximately one to three mg of dry sample was ground into a fine powder with ca $200 \mathrm{mg}$ of $\mathrm{KBr}$ and pressed into a disc. The spectrum was obtained using a Perkin-Elmer "Infracord" spectrophotometer.

\subsection{Mass spectrometry}

Electron impact mass spectra were recorded on a VG 7070F instrument equipped with a VG 2035 Data System. The ionization energy was 70 $\mathrm{eV}$. The ion source temperature was $220^{\circ} \mathrm{C}$.

\subsection{Other methods}

Sephadex G-50 gel filtration was carried out using a $2.5 \times 30 \mathrm{~cm}$ column and an elution medium containing $0.3 \mathrm{M}$-glycerol, $0.1 \mathrm{M}$ Tricine- $\mathrm{NaOH}$ pH 7.9, 1 mM-dithiothreitol and $25 \mathrm{mM}-\mathrm{MgCl}_{2}$. $\delta$-Aminolevulinate was determined as described in (10). Porphobilinogen deaminase, $\delta$-aminolevulinate dehydratase and the aminoacyl ligase were assayed as in (15). Chlorophyll determinations were made as in (2) after extracting the pigments into $80 \%$ acetone.

\section{RESULTS}

3.1. Inhibition of chlorophyll synthesis and accumulation of glutamate 1-semialdehyde in gabaculine treated leaves

Figure 2 illustrates the inhibition of chlorophyll formation in leaves of dark-grown barley

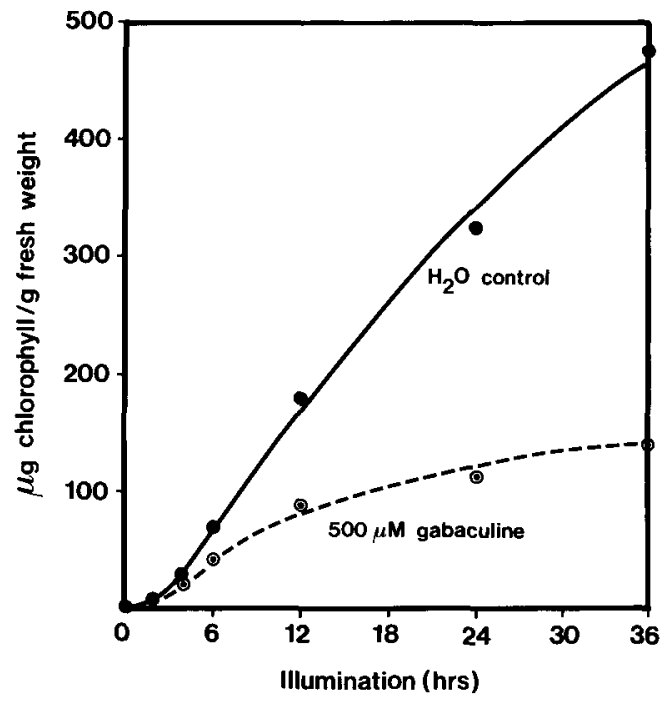

Figure 2. The inhibition of chlorophyll synthesis by gabaculine.

Leaf pieces from 6-day etiolated barley seedlings were fed with gabaculine from cut ends (cf. 2.4). 


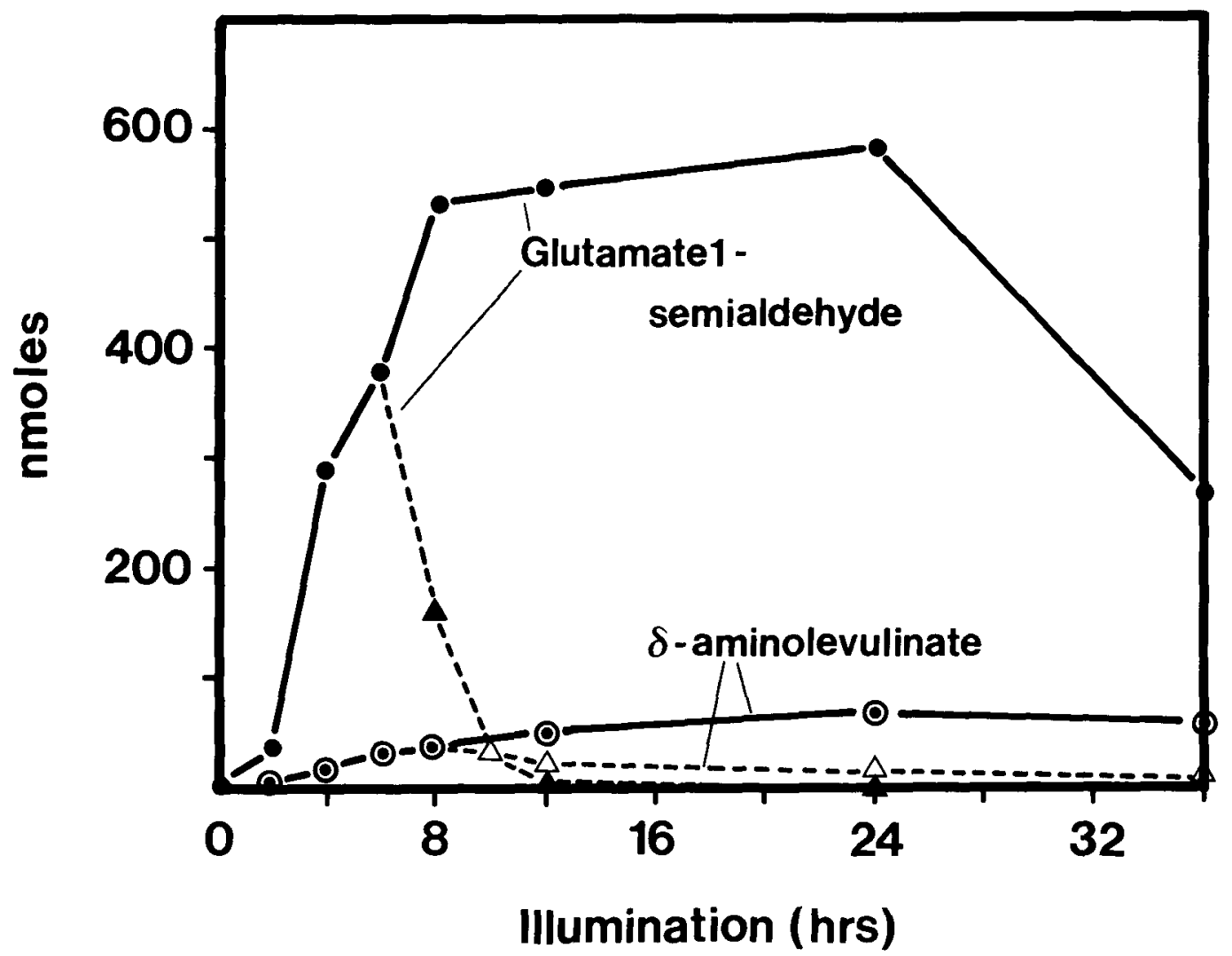

Figure 3. Glutamate 1-semialdehyde accumulation in gabaculine treated leaves.

Five $\mathrm{g}$ portions of leaf segments $(6 \mathrm{~cm})$ from 6-day old dark-grown barley seedlings were held in beakers with their basal ends dipping in $500 \mu \mathrm{M}$-gabaculine and placed in light. After 6 hours of illumination a set of samples were returned to darkness. Leaf samples were analysed at varying times of treatment. Amounts are given in nmoles per $5 \mathrm{~g}$ fresh weight of leaf tissue. __ light, ---- dark.

seedlings treated with $500 \mu \mathrm{M}$-gabaculine. When the untreated etiolated leaf pieces $(6 \mathrm{~cm})$ were placed in light rapid synthesis of chlorophyll occurred after an initial lag. Gabaculine feeding during illumination resulted in a severe inhibition of chlorophyll formation, which was noticable after two hours illumination and became progressively more pronounced with time. After 24 hours of illumination the gabaculine treated leaves contained $34 \%$ of the amount of chlorophyll found in the control leaves. Both the control and gabaculine treated leaf segments exposed to 6 hours light ceased to make chlorophyll when returned to darkness and showed no reduction of the chlorophyll content during the next 30 hours. Glutamate 1-semialdehyde and $\delta$-aminolevulinate accumulated in the leaf segments treated with gabaculine (Figure 3). After two hours of illumination 7 nmoles of glutamate 1 -semialdehyde per $g$ fresh weight was measured. Upon further illumination glutamate 1semialdehyde content increased rapidly and reached 106 nmoles per $g$ fresh weight after 8 hours of light. In the next 16 hours glutamate 1 -semialdehyde accumulated slowly. From 24 to 36 hours there was a decrease in the glutamate 1 -semialdehyde content of the leaves. Gabaculine treated, 6 hours illuminated leaves lost glutamate 1-semialdehyde rapidly when they were placed in darkness. These leaves lost $97 \%$ of their glutamate 1-semialdehyde in six hours of darkness. 
Table I.

Light and aerobic conditions stimulate glutamate 1-semialdehyde accumulation in gabaculine treated leaves.

Leaves from 6 day old dark-grown seedlings were illuminated for 6 hours. In each experiment $5 \mathrm{~g}$ of leaves cut into $1 \mathrm{~cm}$ pieces were infiltrated using $20 \mathrm{ml}$ of liquid in conical flasks. For anaerobic conditions flasks were flushed with $N_{2}$ and closed with a ground glass stopper. The flasks were incubated for 6 hours.

\begin{tabular}{lllc}
\hline $\begin{array}{l}\text { Infiltration } \\
\text { with: }\end{array}$ & $\begin{array}{l}\text { Incubation } \\
\text { in: }\end{array}$ & $\begin{array}{l}\text { Glutamate } \\
\text { 1-semialdehyde }\end{array}$ & $\begin{array}{c}\delta \text {-Amino- } \\
\text { levulinate }\end{array}$ \\
\hline & & nmoles per 5g fresh wt. of leaves \\
1. $\mathrm{H}_{2} \mathrm{O}$ control & light & 0 & 0 \\
2. $500 \mu \mathrm{M}$-Gabaculine & light & 567 & 19 \\
3. “ & light,'anaerobic' & 198 & 1 \\
4. $“$ & dark & 18 & 2 \\
\hline
\end{tabular}

A small amount of $\delta$-aminolevulinate accumulated in response to gabaculine feeding in greening barley leaves. The highest amount observed was 13 nmoles per $\mathrm{g}$ fresh weight after 24 hours in light. The $\delta$-aminolevulinate content of 6 hour-illuminated gabaculine treated leaves declined slowly when these leaves were returned to darkness.

\subsection{Requirements for glutamate 1- semialdehyde accumulation in greening barley leaves}

The effects of gabaculine, light and anaerobic conditions on glutamate 1-semialdehyde accumulation were analysed using leaf pieces from 6 day old dark-grown seedlings illuminated for 6 hours. For this study $1 \mathrm{~cm}$ leaf pieces were infiltrated with $500 \mu \mathrm{M}$-gabaculine as given in 2.5. Glutamate 1 -semialdehyde and $\delta$-aminolevulinate were detected in leaves infiltrated with gabaculine. In darkness, or under anaerobic conditions, these leaves contained respectively $3 \%$ and $35 \%$ of glutamate 1 -semialdehyde found in the segments incubated in the presence of gabaculine in the light (Table I). Since only partially anaerobic conditions can be achieved by flushing the flasks with $\mathrm{N}_{2}$, the 39.6 nmoles glutamate 1-semialdehyde formed per $g$ fresh weight (line 3, Table I) is probably higher than what strictly anaerobic conditions would give. It is concluded that light and aerobic conditions stimulate glutamate 1-semialdehyde accumulation in greening barley leaves.

\subsection{Inhibition of glutamate 1-semialdehyde aminotransferase by gabaculine}

The enzyme glutamate 1-semialdehyde aminotransferase catalyses the last step in the conversion of glutamate to $\delta$-aminolevulinate (7). Gabaculine is a potent inhibitor of this enzyme (Figure 4). Five $\mu \mathrm{M}$ gabaculine included in the assays using purified glutamate 1-semialdehyde aminotransferase resulted in $83 \%$ inhibition. Gabaculine irreversibly inhibits several transaminases (14). Whether the inhibition of glutamate 1-semialdehyde aminotransferase was reversible or not was examined in the following

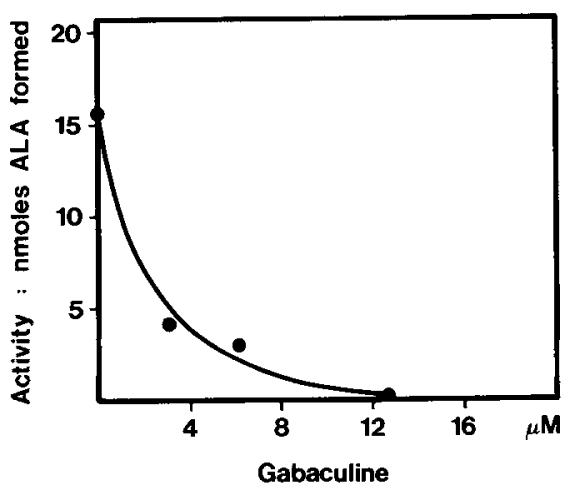

Figure 4. Inhibition of purified glutamate 1-semialdehyde aminotransferase by increasing amounts of gabaculine.

Each assay contained $12 \mu \mathrm{g}$ of enzyme protein and the activity is given in nmoles $\delta$-aminolevulinate formed per assay (cf 2.3). 
Table II.

Gabaculine inhibition of glutamate 1-semialdehyde aminotransferase.

Partially purified enzyme containing $7.3 \mathrm{mg}$ protein $\cdot \mathrm{ml}^{-1}$ was used for each assay. Two $\mathrm{ml}$ of enzyme solution at pH 7.9 was pretreated by incubation for $5 \mathrm{~min}$ at $0{ }^{\circ} \mathrm{C}$ with the compounds indicated and the protein isolated by Sephadex G-50 gel filtration and subsequently assayed as described in 2.4.

Pretreatment
Glutamate 1-semialdehyde aminotransferase activity per mg protein $\%$ control

1. None (Control) 100

2. $500 \mu \mathrm{M}-$ Gabaculine

3. $"+1$ mM-glutamate 1-semialdehyde

way. Three one $\mathrm{ml}$ aliquots (14.6 $\mathrm{mg}$ protein) of partially purified glutamate 1-semialdehyde aminotransferase (cf. 2.3) was adjusted to $\mathrm{pH} 7.9$ by mixing each with one $\mathrm{ml}$ of $0.1 \mathrm{M}$-tricine containing $0.3 \mathrm{M}$-glycerol, $1 \mathrm{mM}$-dithiothreitol and $25 \mathrm{mM}-\mathrm{MgCl}_{2}$. Gabaculine $(500 \mu \mathrm{M})$ was added to each sample followed by either glutamate 1 -semialdehyde $(1 \mathrm{mM})$ or $\delta$-aminolevulinate $(1 \mathrm{mM})$. One sample contained the enzyme mixed with gabaculine alone. After a 5 minute incubation at $0{ }^{\circ} \mathrm{C}$ the protein was isolated by gel filtration on a Sephadex G-50 column and analysed for activity. The enzyme treated with gabaculine alone lost $28 \%$ of its activity (Table II). When treated together with glutamate 1 -semialdehyde or $\delta$-aminolevulinate, the enzyme lost $98 \%$ or $97 \%$ of its activity, respectively.

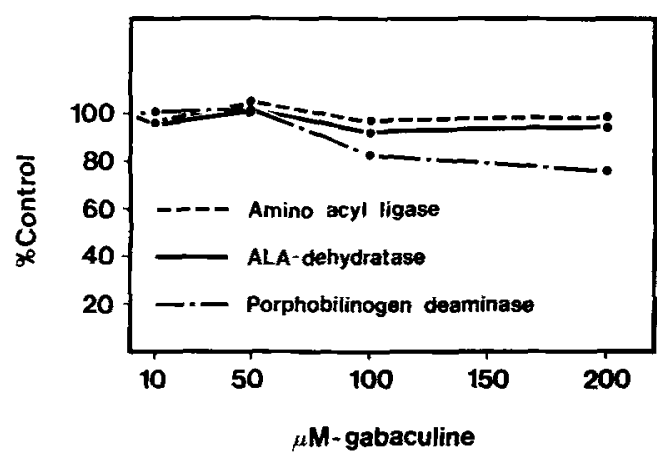

Figure 5. The effect of gabaculine on three enzymes in the chlorophyll biosynthetic pathway.

\subsection{Effect of gabaculine on three other enzymes in the chlorophyll pathway}

The protein fraction that does not bind to the three affinity columns described in $(9,15)$ was used to test the effect of gabaculine on $\delta$-aminolevulinate dehydratase, porphobilinogen deaminase and the aminoacyl ligase involved in $\delta$-aminolevulinate synthesis. Gabaculine $(200 \mu \mathrm{M})$ inhibited porphobilinogen deaminase activity by $23 \%$ (Figure 5 ). Tested up to $200 \mu \mathrm{M}$, gabaculine had no significant effect on the other two enzymes examined.

\subsection{Identity of biosynthetic glutamate 1- semialdehyde}

Glutamate 1-semialdehyde was isolated from greening barley leaves treated with gabaculine. It was purified as the hydrochloride and compared with the chemically synthesised compound by mass and infrared spectroscopy. The mass spectrum of the biosynthetic glutamate 1-semialdehyde hydrochloride was identical to that of the chemically synthesised compound. It was not possible to identify a peak corresponding to the molecular ion. The mass to charge ratios and the relative intensities of the major peaks were: $84(100 \%), \quad 56(4.7 \%), \quad 41(14.9 \%), \quad 38(7.4 \%)$, $36(22.9 \%), 35(2 \%)$. The base peak with $\mathrm{m} / \mathrm{e}$ of 84 probably corresponds to the ion $\mathrm{CH}_{2}-\mathrm{CH}_{2}-\mathrm{CH}=\mathrm{N}, \mathrm{H}-\mathrm{C}=\mathrm{O}$ derived from the molecular ion by the loss $\mathrm{H}_{2} \mathrm{O}$ and $\mathrm{CHO}$. The peaks at $\mathrm{m} / \mathrm{e} 36$ and at 38 represent $\mathrm{HCl}$. The spectrum also had peaks at $\mathrm{m} / \mathrm{e} 85(5 \%), 101(<1 \%)$, $102(<1 \%)$ and $129(3 \%)$. 


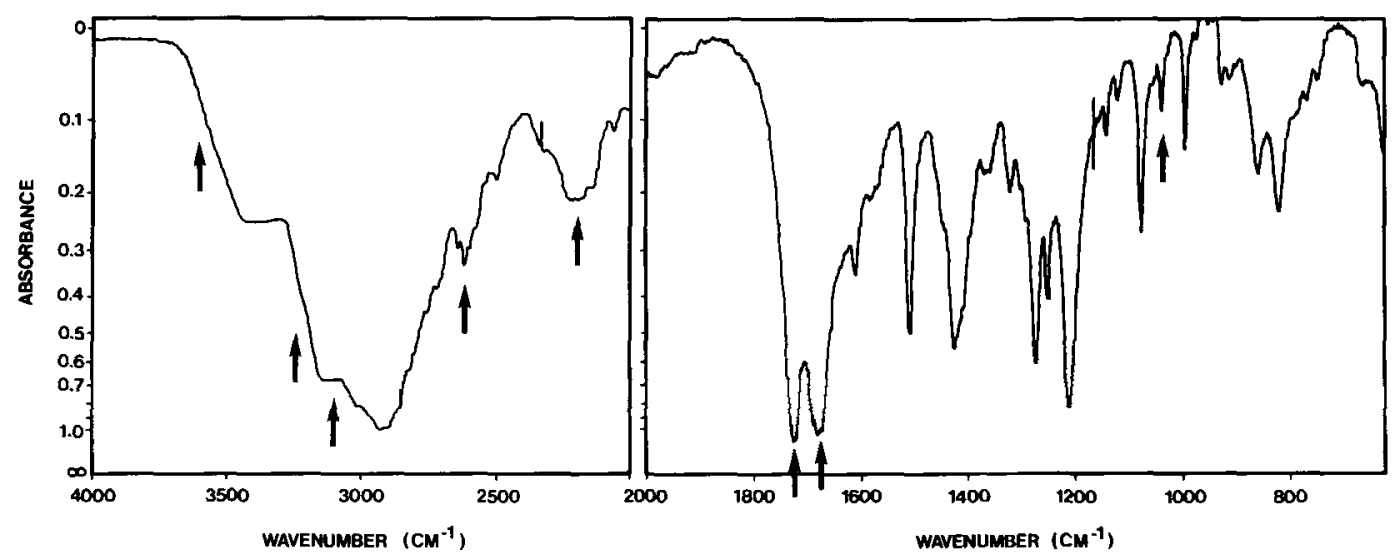

Figure 6. The infrared spectrum of glutamate 1-semialdehyde hydrochloride isolated from gabaculine treated leaves.

The disc contained $3.2 \mathrm{mg}$ in $210 \mathrm{mg}$ of $\mathrm{KBr}$. Arrows demarkate the absorptions assigned in text.

The infrared spectra of biosynthesised and chemically synthesised glutamate 1-semialdehyde were quite similar (Figures 6 and 7, respectively). The broad absorption band around 3100 $\mathrm{cm}^{-1}$, and the sharp bands at $1510 \mathrm{~cm}^{-1}$ and at $1080 \mathrm{~cm}^{-1}$ are assigned to the amino group of glutamate 1-semialdehyde. The broad band extending from 3600 to $3200 \mathrm{~cm}^{-1}$, is assigned to stretching of the $\mathrm{OH}$ of the carboxylic acid group. The peaks at 1730 and $1680 \mathrm{~cm}^{-1}$ are characteristic for glutamate 1-semialdehyde hydrochloride. The peak at $1730 \mathrm{~cm}^{-1}$ is assigned to the $\mathrm{COOH}$ group and the peak at $1680 \mathrm{~cm}^{-1}$ is assigned to the aldehyde group in close association with the amino group. The peaks at 2620 is also assigned to the $\mathrm{COOH}$ group. Compared to chemically synthesised glutamate 1 -semialdehyde hydrochloride the compound isolated from gabaculine treated leaves had two additional infrared light absorbing peaks (broad peak at $2200 \mathrm{~cm}^{-1}$ and a sharp peak at $1040 \mathrm{~cm}^{-1}$ ). These two peaks probably originate from impurities and it is concluded that biosynthetic glutamate 1-semialdehyde hydrochloride is identi-

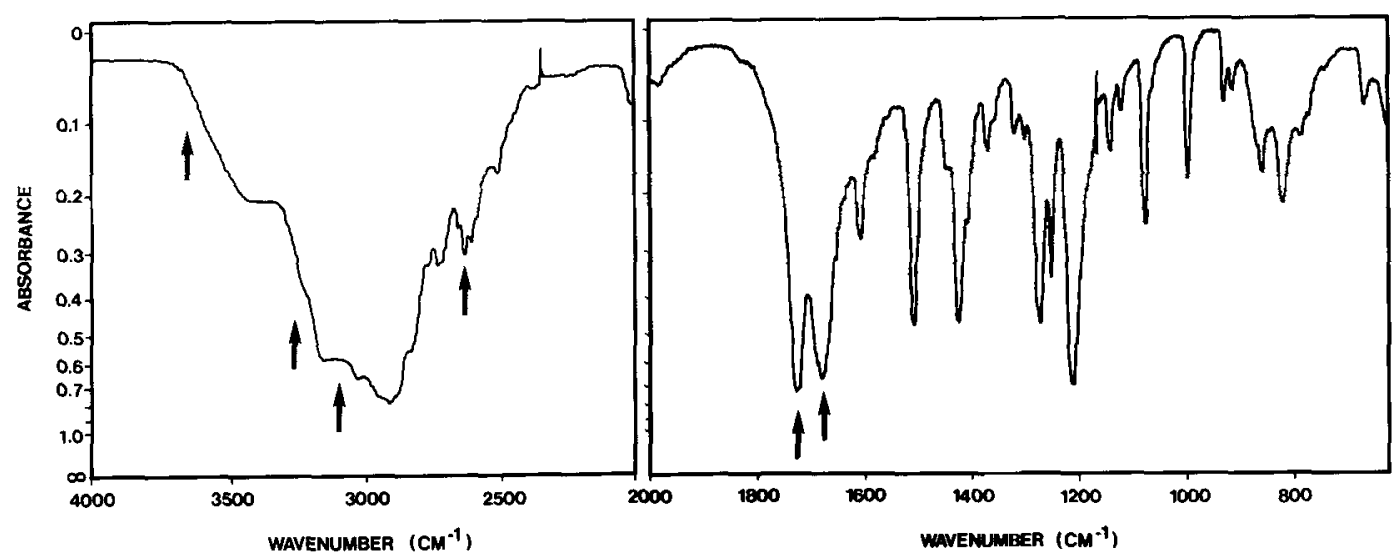

Figure 7. The infrared spectrum of chemically synthesised glutamate 1-semialdehyde hydrochloride.

The disc contained $3.3 \mathrm{mg}$ in $208 \mathrm{mg}$ of $\mathrm{KBr}$. Arrows demarkate the absorptions assigned in text. 

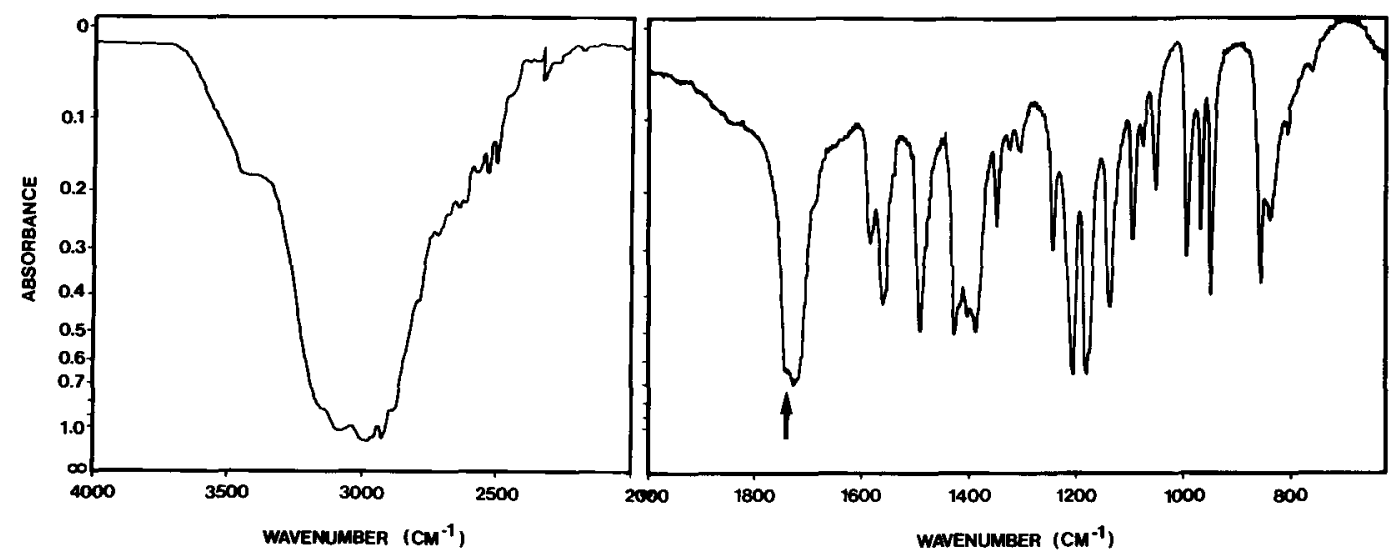

Figure 8. The infrared spectrum of $\delta$-aminolevulinic acid hydrochloride.

The disc contained $1.5 \mathrm{mg}$ in $190 \mathrm{mg}$ of $\mathrm{KBr}$. Arrows indicate a peak assigned in text.

cal to the chemically synthesised compound. The infrared spectrum of glutamate 1-semialdehyde hydrochloride is clearly different from the infrared spectrum of either $\delta$-aminolevulinate hydrochloride (Figure 8 ) or L-glutamate acid (Figure 9). The absorption at $1730 \mathrm{~cm}^{-1}$ in the infrared spectrum of $\delta$-aminolevulinic acid arises from two overlapping peaks from the two carbonyl groups one from $\mathrm{COOH}$ and other from ketone. Neither $\delta$-aminolevulinic acid nor glutamic acid gave absorption peaks at $2200 \mathrm{~cm}^{-1}$ and $1040 \mathrm{~cm}^{-1}$. Therefore, $\delta$-aminolevulinic acid and glutamic acid are eliminated as possible impurities in biosynthetic glutamate 1-semialdehyde hydrochloride.

\subsection{Stability of glutamate 1-semialdehyde}

The stability of the chemically synthesised glutamate 1-semialdehyde was investigated using the glutamate 1-semialdehyde aminotransferase assay. In one experiment, the chemically synthesised glutamate 1 -semialdehyde was eluted from the Dowex $50 \times 8$ column using 0.2 $\mathrm{M}$-pyridine-acetate buffer $\mathrm{pH}$ 5.1. The fractions containing glutamate 1-semialdehyde were

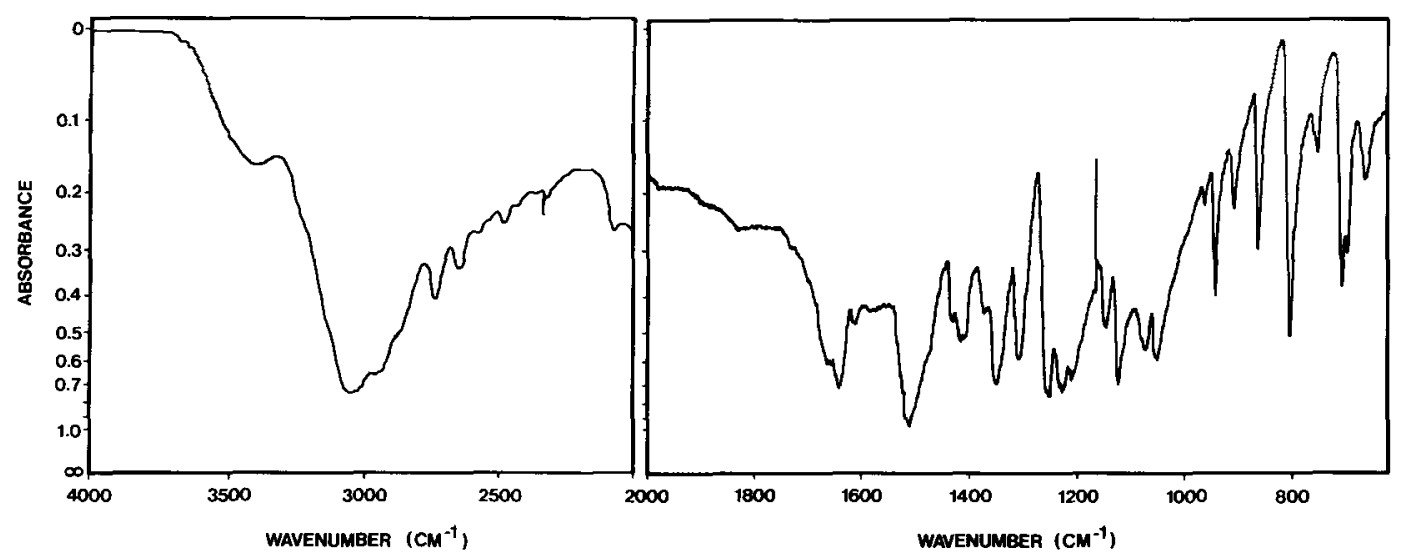

Figure 9. The infrared spectrum of L-glutamic acid.

The disc contained $1.1 \mathrm{mg}$ in $212 \mathrm{mg}$ of $\mathrm{KBr}$. 
Table III.

The stability of glutamate 1-semialdehyde hydrochloride.

Chemically synthesised glutamate 1-semialdehyde hydrochloride was analysed before and after storage as indicated using the glutamate 1-semialdehyde aminotransferase assay given in 2.4 .

Experiment

Glutamate 1-semialdehyde aminotransferase nmoles of $\delta$-aminolevulinate formed per $\mu$ mole of substrate

1. Before storage

2. $1 \mathrm{M}$ solution 2 weeks after storage at:
a) $4{ }^{\circ} \mathrm{C}$
b) $-20{ }^{\circ} \mathrm{C}$, frozen

3. Solid 1 week after storage at:

a) room temperature (ca $22{ }^{\circ} \mathrm{C}$ ) 4.2

b) $-20^{\circ} \mathrm{C}$

pooled and lyophilised. This gave the free base as a white powder. Immediately after lyophilisation it was active in the aminotransferase assay. The material turned brown and lost all its activity after storage over a weekend at $-20^{\circ} \mathrm{C}$. It was therefore concluded that as a free base glutamate 1-semialdehyde is unstable. The instability is probably due to spontaneous polymerisation. By lyophilising the preparations in the presence of $\mathrm{HCl}$, glutamate 1-semialdehyde hydrochloride is obtained as a white crystalline powder. This material is very soluble in water and a $1 \mathrm{M}$ solution has a $\mathrm{pH}$ of 1.3. Samples of glutamate 1-semialdehyde hydrochloride were stored for two weeks both in solid form and as 1 $M$ aqueous solution at $4{ }^{\circ} \mathrm{C}$ and at $-20^{\circ} \mathrm{C}$ and assayed as substrate for glutamate 1-semialdehyde aminotransferase. The solid was also tested after one week of storage at room temperature (ca $22{ }^{\circ} \mathrm{C}$ ). These tests showed no loss of glutamate 1-semialdehyde (Table III) and we conclude that :glutamate 1-semialdehyde hydrochloride, as a dry solid, is suitable for storage.

\section{DISCUSSION}

Significant amounts of glutamate 1-semialdehyde accumulated in barley leaves when chlorophyll formation was inhibited by gabaculine treatment. Furthermore, gabaculine is a potent inhibitor of glutamate 1-semialdehyde amino- transferase. These observations provide direct evidence for the participation of glutamate 1semialdehyde as an intermediate in the chlorophyll biosynthetic pathway. The amount of glutamate 1-semialdehyde accumulated in gabaculine treated leaves was, however, not sufficient to account for the amount of chlorophyll that failed to accumulate or even the amount of $\delta$-aminolevulinate that would accumulate if similar leaves were treated with 20 mM-levulinate (5). This is probably due to conversion of a part of the glutamate 1 -semialdehyde to glutamate by oxidation. In a previous study a protein fraction that seems to oxidise glutamate 1-semialdehyde to glutamate was detected in the stroma of greening barley plastids (8). We suggest that the rapid decline of glutamate 1-semialdehyde in gabaculine treated leaves when they are returned to darkness (cf. Figure 3) likewise results from the activity of an oxidase.

Light and aerobic conditions stimulate glutamate 1-semialdehyde accumulation in gabaculine treated greening barley leaves (Table I). Light and aerobic conditions also stimulate $\delta$-aminolevulinate accumulation in levulinate treated leaves (1). These effects probably arise from a common cause. We suggest that light and aerobic conditions act indirectly, by providing ATP and NADPH required, respectively, for the aminoacyl ligase and the dehydrogenase involved in the pathway of glutamate to $\delta$-ami- 
nolevulinate (9). Small amounts of $\delta$-aminolevulinate accumulated in greening barley leaves treated with $500 \mu \mathrm{M}$-gabaculine. However, gabaculine (tested up to $200 \mu \mathrm{M}$ ) had no effect on $\delta$-aminolevulinate dehydratase present in a protein fraction partially purified from the chloroplast stroma. This indicates the presence of an additional $\delta$-aminolevulinate dehydratase in greening barley leaves which is sensitive to gabaculine and possibly located outside the plastids.

Gabaculine acts as a neurotoxin in animals. It inhibits $\gamma$-aminobutyrate transaminase by reacting with the aldehyde group of the pyrodoxal phosphate present in the enzyme, resulting in irreversible inactivation (11). Several other pyridoxal dependent enzymes are similarly inhibited by gabaculine. It is not known whether glutamate 1-semialdehyde aminotransferase contains pyridoxal phosphate or pyruvate as coenzyme (cf. 12), but our results show that gabaculine is an effective inhibitor for the enzyme in the presence of either its substrate or its product.

In this investigation mass and infra red spectra were used to establish that biosynthetic glutamate 1-semialdehyde has the same structure as the chemically synthesised compound. These spectra support the structure of glutamate 1semialdehyde previously established (6). However, it is not certain that the compound exists as an aminoaldehyde in solution, and as such, serves as the substrate for the enzyme. It is hoped that this can be determined by carbon 13 and proton nuclear magnetic resonance spectra of solutions of glutamate 1-semialdehyde hydrochloride.

\section{ACKNOWLEDGEMENTS}

Dr. JøRN ØGAARD MADSEN at the Department of Organic Chemistry of the Technical University of Denmark is gratefully acknowledged for performing the mass spectrometric analyses on glutamate 1-semialdehyde. We wish to thank Dr. SimON P. GoUGH and Professor DITER VON WETTSTEIN for critically reading the manuscript, Mrs. BIRGIT STADEL for technical assistance and Mrs. NINA RASMUSSEN for drawing the figures. This research was supported in part by research contract No. GB 1-4-024DK of the Biomolecular engineering programme of the Commission of the European Community to Professor D. von WETtSTEIN.

\section{REFERENCES}

1. Beale, S. I. \& P. A. Castelfranco: The biosynthesis of $\delta$-aminolevulinic acid in higher plants 1. Accumulation of $\delta$-aminolevulinic acid in greening plant tissues. Plant Physiol. 53, 291-296 (1974)

2. BRUINSMA, J.: A comment on the spectrophotometric determination of chlorophyll. Biochem. Biophys. Acta 52, 576-578 (1961)

3. DAVIS, B. J.: Disc electrophoresis II. Method and application to human serum proteins. Annals New York Acad. Sciences 121, 404-427 (1964)

4. FLINT, D. H.: Gabaculine inhibits $\delta$-ALA synthesis in chloroplasts. Plant Physiol. 75, suppl. p. 170 (1984)

5. Gough, $S$.: Light stimulated $\delta$-aminolevulinate accumulation in levulinate treated barley seedlings. Carlsberg Res. Commun. 43, 497-508 (1978)

6. Houen, G., S. P. Gough \& C. G. Kannangara: $\delta$-Aminolevulinate synthesis in greening barley $\mathrm{V}$. The structure of glutamate 1-semialdehyde. Carlsberg Res. Commun. 48, 567-572 (1984)

7. Kannangara, C. G. \& S. P. Gough: Biosynthesis of $\delta$-aminolevulinate in greening barley leaves: Glutamate 1-semialdehyde aminotransferase. Carlsberg Res. Commun. 43, 185-194 (1978)

8. KanNangara,C.G.,S.P.Gough \& C.R. GirNTH: $\delta$-Aminolevulinate synthesis in greening barley 2 . Purification of enzymes. In: 5th Int. Congr. Photosynthesis V. Chloroplast development. G. Akoyunoglou ed. Balaban International Science Services. Philadelphia. pp. 117-127 (1981)

9. Kannangara, C. G., S. P. Gough, R. P. Oliver \& S. K. Rasmussen: Biosynthesis of $\delta$-aminolevulinate in greening barley leaves VI. Activation of glutamate by ligation to RNA. Carlsberg Res. Commun. 49, 417-437 (1984)

10. Mauzerall, D. \& S. Granick: The occurrence and determination of $\delta$-aminolevulinic acid and porphobilinogen in urine. J. Biol. Chem. 219, 435-466 (1956)

11. RANDO, R. R.: Mechanism of the irreversible inhibition of $\gamma$-aminobutyric acid- $\alpha$-ketoglutaric acid transaminase by the neurotoxin gabaculine. Biochemistry 16, 4604-4610 (1977)

12. Recsei, P. A. \& E. E. Snell: Pyruvoyl enzymes. Ann. Rev. Biochem. 53, 357-387 (1984) 
13. Sawicki, E., T. R. Hauser, T. W. Stanley \& W. ElBERT: The 3-methyl-2-benzothiazolone hydrazone test. Sensitive new methods for the detection, rapid estimation and determination of aliphatic aldehydes. Analytical Chem. 33, 93-96 (1961)

14. SOPER, T. S. \& J. M. MANNING: Inactivation of pyridoxal phosphate enzymes by gabaculine. Cor-

Accepted by S. O. ANDERSEN relation with enzymic exchange of $\beta$ protons. $J$. Biol. Chem. 257, 13930-13936 (1982)

15. WANG, W.-Y., S.P.Gough \& C.G. Kannangara: Biosynthesis of $\delta$-aminolevulinate in greening barley leaves IV. Isolation of three soluble enzymes required for the conversion of glutamate to $\delta$-aminolevulinate. Carlsberg Res. Commun. 46, 243257 (1981) 